\title{
Current guidelines for prostate cancer screening: A systematic review and minimal core proposal
}

\author{
Fernando Antonio Glasner da Rocha Araujo ${ }^{1 *} \bullet$, Ubirajara Oliveira JR² \\ ${ }^{1}$ Adjunct Professor, Internal Medicine Department, Faculdade de Medicina da Bahia, Universidade Federal da Bahia, Salvador, BA, Brazil \\ 2Professor, Medicine and Health Graduate Program, Escola Bahiana de Medicina e Saúde Pública, Salvador, BA, Brazil
}

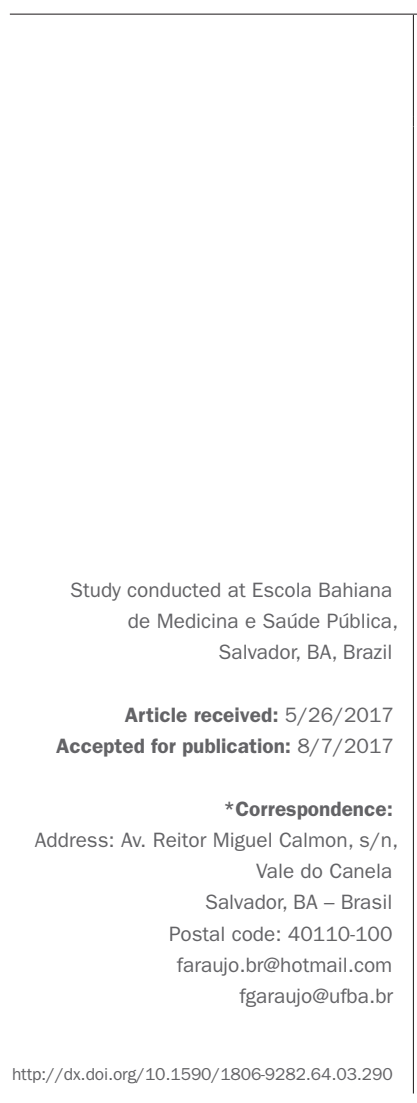

\section{SUMMARY}

Objective: Considering the importance of screening for prostate cancer, the possibility of damage resulting from indiscriminate screening and the difficulty of disclosure and adherence to the main guidelines on the subject, we aimed to identify current guidelines, look for common approaches and establish a core of conducts.

Method: Systematic review of the literature on screening practice guidelines for prostate cancer searching the databases PubMed, Lilacs and Google Scholar and active search in the sites of several national health entities.

Results: Twelve (12) guidelines were selected, whose analysis resulted in the identification of six common points of conduct, with the following minimum core of recommendations: (1) screening indication or not: must be individualized, and preceded by an informed decision; (2) tests used: PSA with or without rectal digital examination; (3) age at which initiate testing in men in general risk: 50-55 years; (4) age at which to initiate testing in men at increased risk: $40-45$ years; (5) the interval between screening: annual or biennial; and (6) age at which to discontinue testing: 70 years-old or life expectancy less than 10 years.

Conclusion: Although there are differences between them, it was possible to establish a minimum core of conducts that may be useful in the daily practice of the physician.

Keywords: Mass Screening. Prostatic Neoplasm. Practice Guideline.

\section{INTRODUCTION}

Prostate cancer (PCa) is one of the leading causes of mortality among men worldwide. ${ }^{1}$ In Brazil alone, 70.42 new cases per 100,000 men are estimated per year. ${ }^{2}$

For many years, screening for early detection of prostate cancer relied solely on digital rectal examination. During that period, most cancers were diagnosed in advanced stages, with no effect on mortality reduction. With the introduction of prostate-specific antigen (PSA) determination as a screening test, there was a dramatic increase in PCa diagnosis, especially in the early stages, followed by a reduction in mortality. ${ }^{3}$ These figures stimulated the use of PSA testing for the early diagnosis of PCa, thanks also to the recommendation of several scientific societies.

Nevertheless, the publication of two large randomized trials has shown conflicting results on the ability of such screening for PCa to reduce mortality. ${ }^{4,5}$ For these reasons, and due to the possibility of causing harm, screening for prostate cancer (SPCa) is one of the most controversial medical topics.

In an effort to maximize benefits and minimize harm, several government and scientific entities have issued recommendations for the screening of prostate cancer. ${ }^{6-17}$

Two problems, however, reduce the potential benefit that might derive from the issuing of these guidelines: any existing contradictions among them, ${ }^{18}$ or insufficient disclosure or adoption thereof. ${ }^{19}$ By means of a systematic review, our study aimed at (1) identifying the most up-to-date guidelines for PCa screening from the main national and international medical and governmental entities; (2) comparing the main recommendations of each one; and then (3) proposing a minimum core set of recommendations representing the majority of the overall recommendations that can be easily assimilated and implemented by the clinician. 


\section{Method}

We conducted a systematic review according to the PRISMA (Preferred Reporting Items for Systematic Reviews and Meta-Analyses) recommendations. ${ }^{20}$

\section{Search strategy}

We employed three survey strategies. (1) Medical articles surveyed in the PubMed and Scielo databases. The terms we searched in the former were: (( cancer of prostate[MeSH Terms]) AND guideline[Title]) OR recommendation[Title]) AND screening[Title/Abstract]; whereas the terms we searched in the latter were "rastreamento" AND "cancer" AND "prostata;" (2) Complementary search of articles in the Google Scholar database. Search terms: Prostate cancer screening guidelines recommendations; (3) Active search on the websites of several national scientific entities for recommendations or practical guides. We surveyed the following websites: the Brazilian Association of Preventive Medicine (Associação Brasileira de Medicina Preventiva), the Brazilian Medical Association (Associação Médica Brasileira), the National Cancer Institute (Instituto Nacional do Câncer), the Ministry of Health (Ministério da Saúde), the Brazilian Society of Cancerology (Sociedade Brasileira de Cancerologia), the Brazilian Society of Clinical Medicine (Sociedade Brasileira de Clínica Médica), the Brazilian Society of Geriatrics and Gerontology (Sociedade Brasileira de Geriatria e Gerontologia), the Brazilian Society of Clinical Oncology (Sociedade Brasileira de Oncologia Clínica) and the Brazilian Society of Urology (Sociedade Brasileira de Urologia).

\section{Characteristics of the studies}

We selected published studies with the endorsement from different scientific societies (urology, oncology, internal medicine, preventive medicine) and from government regulatory agencies, and encompassing different study type, namely consensus, recommendations and practical guides on prostate cancer screening.

\section{Delimitation}

We narrowed our study by publication date (2010-2016) so as to include recommendations that had the opportunity to evaluate the two major randomized prostate cancer screening trials. ${ }^{5,4}$ We limited the publication languages to English, Portuguese and Spanish, and the population to adult men.

The last search date was March 10, 2017.

After we chose the articles, we proceeded to identify the common discussion points in order to establish a minimum core set of recommendations commonly shared by most of the studies selected.

\section{Results and Discussion}

By following the survey strategy, we initially found 110 articles on PubMed and another 20 on Scielo. After reading the title and abstract, we excluded 124 articles because they did not meet our study's goals. Of the six pre-selected articles, we excluded one because it was the previous version of an existing recommendation among the remainder of the articles. We included four new articles from searching Google Scholar and another two from searching the national entities' websites, which resulted in a total of eleven analyzed recommendations. ${ }^{6-16}$

After the date of the systematic review, a US Preventive Service Task Force draft recommendation ${ }^{17}$ was published for public consultation, suggesting a change in its recommendation in force. ${ }^{16}$ We considered both, though, which increased to twelve the number of recommendations we analyzed.

The analysis of the recommendations allowed us to identify six common points in our analysis: (1) whether there was an indication for screening or not; (2) examinations used; (3) age of onset for screening in men at general risk; (4) age of onset in men at increased risk; (5) interval between screenings; and (6) age of screening discontinuation (Chart 1).

\section{ShOULD SCREening for PRostate CANCER BE INDICATED?}

Currently, only one entity recommends against screening any given patient - the European Society for Medical Oncology (ESMO). ${ }^{12}$ Until not long ago, this was also the recommendation from the US Preventive Services Task Force (USPSTF). ${ }^{16}$ However, they recently published a draft recommendation for public consultation where they admit to offering screening for men aged 55-69 years. ${ }^{17}$

The Canadian Task Force (CTFPHC) and Brazil's National Cancer Institute (Inca, Instituto Nacional de Câncer) advise the physician not to offer the screening, so that it is performed only on the patient's demand for those aged 55-69 years or those at increased risk of prostate cancer. ${ }^{6,13}$ The stand of these entities, as well as that of all others, is that the current state of knowledge on the early detection of prostate cancer cannot support a definitive decision either to indicate or to contraindicate the screening. The decision must be made by the patient himself, through an informed decision process, or shared with his physician. If the patient still does not feel able to make a decision even after receiving the information, his doctor may make the decision instead, based on what she or he knows of her/his patient's values and preferences. These recommendations indicate not only the need 
CHART 1 Summary of the guidelines from the entities recommending the screening for prostate cancer.

\begin{tabular}{|c|c|c|c|c|c|c|c|}
\hline $\begin{array}{l}\text { Entity and } \\
\text { reference }\end{array}$ & $\begin{array}{l}\text { American } \\
\text { Cancer } \\
\text { Society }^{7}\end{array}$ & $\begin{array}{l}\text { American } \\
\text { College of } \\
\text { Physycians }^{8}\end{array}$ & $\begin{array}{l}\text { American } \\
\text { Urological } \\
\text { Association }^{9}\end{array}$ & $\begin{array}{l}\text { Canadian } \\
\text { Urological } \\
\text { Association }^{10}\end{array}$ & $\begin{array}{l}\text { European } \\
\text { Association } \\
\text { of Urology }{ }^{11}\end{array}$ & $\begin{array}{l}\text { Sociedade } \\
\text { Brasileira de } \\
\text { Urologia }^{15}\end{array}$ & $\begin{array}{l}\text { National } \\
\text { Comprehensive } \\
\text { Cancer Network }^{14}\end{array}$ \\
\hline Year & 2010 & 2013 & 2013 & 2011 & 2014 & 2011 & 2015 \\
\hline $\begin{array}{l}\text { Should SPCa be } \\
\text { performed? }\end{array}$ & $\begin{array}{l}\text { Yes, for men with } \\
\text { decision process }\end{array}$ & a life expectancy & y greater than $10-$ & 15 years, who requ & uire it following ar & ed & $\begin{array}{l}\text { Yes, after a discussion } \\
\text { about risk and benefit }\end{array}$ \\
\hline Mass campaigns & $\begin{array}{l}\text { Recommends } \\
\text { against }\end{array}$ & $\begin{array}{l}\text { Recommends } \\
\text { against }\end{array}$ & $\begin{array}{l}\text { Recommends } \\
\text { against }\end{array}$ & NC & $\begin{array}{l}\text { Recommends } \\
\text { against }\end{array}$ & NC & $\begin{array}{l}\text { Recommends } \\
\text { against }\end{array}$ \\
\hline Mode & $\begin{array}{l}\text { PSA alone or } \\
\text { PSA+DRE }\end{array}$ & $\begin{array}{l}\text { PSA with or } \\
\text { without DRE }\end{array}$ & PSA & $\begin{array}{l}\text { Total PSA and } \\
\text { total/free ration, } \\
\text { and DRE }\end{array}$ & PSA and DRE & PSA and DRE & $\begin{array}{l}\text { PSA with or without } \\
\text { DRE }\end{array}$ \\
\hline $\begin{array}{l}\text { Age of onset, } \\
\text { no additional risk }\end{array}$ & $\begin{array}{l}\text { General } \\
\geq 50 \text { years }\end{array}$ & General 50-69 & $\begin{array}{l}\text { General } \\
55-69 \text { years }\end{array}$ & $\begin{array}{l}\text { General } \\
\geq 50 \text { years }\end{array}$ & $\begin{array}{l}\text { General } \\
\geq 50 \text { years }\end{array}$ & $\begin{array}{l}\text { General } \geq 50 \\
\text { years }\end{array}$ & 45 years \\
\hline $\begin{array}{l}\text { Age of onset for } \\
\text { increased risk }\end{array}$ & $\begin{array}{l}\text { High risk } \\
\geq 45 \text { years } \\
\text { Highest risk } \\
\geq 40 \text { years }\end{array}$ & Same as above & $\begin{array}{l}\text { Higher risk: } \\
\text { 40-54 years }\end{array}$ & $\begin{array}{l}\text { Higher risk } \geq \\
40 \text { years }\end{array}$ & $\begin{array}{l}\text { Higher risk } \geq \\
45 \text { years }\end{array}$ & $\begin{array}{l}\text { Higher risk } \geq \\
45 \text { years }\end{array}$ & $N C$ \\
\hline $\begin{array}{l}\text { Interval between } \\
\text { screenings }\end{array}$ & $\begin{array}{l}\text { Annual if PSA } \\
\geq 2.5 \mathrm{ng} / \mathrm{mL} \\
\text { Biennial if PSA } \\
<2.5 \mathrm{ng} / \mathrm{mL}\end{array}$ & $\begin{array}{l}\text { Annual if PSA } \\
>2.5 \mathrm{ng} / \mathrm{dL} \\
\text { Does not } \\
\text { define it for } \\
\text { other values }\end{array}$ & Biennial & Annual & 2-8 years & $\mathrm{NC}$ & $\begin{array}{l}1-2 \text { years if PSA } \\
\geq 1 \mathrm{ng} / \mathrm{mL} \\
2-4 \text { years if PSA } \\
<1 \mathrm{ng} / \mathrm{dL}\end{array}$ \\
\hline $\begin{array}{l}\text { Age of } \\
\text { discontinuation }\end{array}$ & $\begin{array}{l}\text { Life expectancy } \\
\text { less than } 10 \\
\text { years }\end{array}$ & $\begin{array}{l}\text { Life expectancy } \\
\text { less than } \\
10-15 \text { years } \\
\text { Age }>70 \text { years }\end{array}$ & $\begin{array}{l}\text { Life expectancy } \\
\text { less than } \\
10-15 \text { years } \\
\text { Age }>70 \text { years }\end{array}$ & $\begin{array}{l}\text { Life expectancy } \\
\text { less than } 10 \\
\text { years }\end{array}$ & $\begin{array}{l}\text { Life expectancy } \\
\text { less than } 15 \\
\text { years }\end{array}$ & $\begin{array}{l}\text { Life } \\
\text { expectancy } \\
\text { less than } 10 \\
\text { years }\end{array}$ & $\begin{array}{l}\text { Life expectancy less } \\
\text { than } 10 \text { years } \\
\text { or age }> \\
75 \text { years* }\end{array}$ \\
\hline
\end{tabular}

SPCa: screening for prostate cancer; DRE: digital rectal examination; PSA: prostate-specific antigen; NC: not commented or addressed. $\left({ }^{*}\right)$ Patients over 75 years of age with excellent health and no comorbidities can continue to be screened. The guidelines from CTFPHC, ${ }^{6}$ ESMO, ${ }^{12}$ INCA $^{13}$ and the USPSTF ${ }^{16}$ are not depicted in the chart because they do not contribute to the above recommendations given that they do not recommend screening.

for a visit to a doctor, but also prior and reasonable knowledge of the doctor about his patient. For this reason, all the entities engaged in discussing this matter are against community screening campaigns. . $^{7-911,16}$

Regarding the patient's values, the physician should differentiate (a) those who value an early finding of cancer, even if that might put him at the risk of undergoing unnecessary treatment and sustaining collateral harm; from (b) those who value avoiding potential harms from the screening and treatment, even if that might put him at the risk of finding an aggressive cancer for which there is no further treatment in the future.

This conversation with the patient on the possible benefits and harms from screening is the most important - and also the most difficult - topic on this subject. Its complexity and the lack of time during visits are the most commonly encountered difficulties. ${ }^{21}$ Furthermore, it is very difficult for the doctor to be truly impartial. There is evidence that these conversations tend to value benefits and minimize harm. ${ }^{22}$
The American Cancer Society (ACS), ${ }^{7}$ the American College of Physicians (ACP) ${ }^{8}$ and the Canadian Task Force on Preventive Health Care (CTFPHC) ${ }^{6}$ all suggest a set of information that should be shared with the patient so that he can reach an informed decision (Chart 2). The USPSTF provides a flow chart (as supplementary material to the article) that facilitates the patient's understanding of the figures involved in his decision. ${ }^{17}$

\section{WHICH SCREENING TESTS SHOULD BE USED?}

Although there are currently several new markers proposed for PCa screening, ${ }^{23}$ the revised guidelines recommend that only PSA be used either alone or in association with digital rectal examination (DRE).

The role of DRE is controversial. As far as screening is concerned, DRE appears to have little ${ }^{7}$ or nothing ${ }^{10}$ to add to PSA testing, and cancers detected by DRE alone tend to be low-grade tumors with a low potential for lethality. Therefore, the ACS recognizes its aiding role in assessing patients 
CHART 2 Points for discussion with the patient to facilitate an informed decision.

Screening for prostate cancer is still a controversial subject, and there is no consensus among experts

Screening (PSA either alone or combined with digital rectal examination) can detect prostate cancer before it would be detected without screening; however, the PSA test cannot differentiate whether a cancer is severe or not, or whether the examination result is increased even without the presence of cancer. Still, in men with PSA > $10 \mathrm{ng} / \mathrm{dL}$, treatment will have a greater chance of reducing the possibility of death

The PSA test is not "just a blood test." It may trigger the beginning of a process of further examinations and treatments for which the person must be alert and prepared. In this process, there is more chance of harms than benefits, and the patient should be quite sure about what he wishes to do. For this reason, it is necessary to discuss any findings with his physician before deciding whether to undergo screening for prostate cancer Of every 1,000 men who choose to take the screening test, five will die from prostate cancer. Among those who choose not to, $6: 1,000$ die from prostate cancer. Hence, screening for prostate cancer saves one man from death for every 1,000 men screened

Most men who choose not to be screened will not have a prostate cancer diagnosed and will die from another cause. This occurs because the clear majority of prostate cancers are slow-growing and do not lead to death

Depending on the treatment chosen, it can lead to urinary, intestinal, sexual and other disorders. These problems can be minimal or significant, temporary or permanent. For every 1,000 men who are treated for prostate cancer, about 280 will have erectile dysfunction, up to 170 will have urinary incontinence, whereas another 4 to 5 will die from the treatment

PSA and digital rectal examination may produce false-positive and false-negative results, which means that men without cancer may have abnormal results and thus undergo other tests unnecessarily or have clinically significant cancers but still get normal test results. False-positive results may lead to permanent anxiety about the possibility of having prostate cancer

Abnormal PSA or DRE results do require prostate biopsy. The procedure can be painful, lead to complications such as infection and bleeding, and may not indicate the presence of significant cancer. One study showed that the chance of dying after a biopsy is $2 / 1,000(0.2 \%)$

Not all men who have a cancer detected by screening require immediate treatment, but they may require periodic blood tests and prostate biopsy for future decision-making

There are several ongoing studies that could modify current ideas and recommendations on prostate cancer screening. The patient can, at any given time, change his opinion on screening, starting it or interrupting it when he so wishes

Adapted from Wolf et al., ${ }^{7}$ Qassem et al. ${ }^{8}$ and Bell et al. ${ }^{6}$

DRE: digital rectal examination; PSA: prostate-specific antigen.

with PSA in the so-called "gray range" (2.5-4.0 ng/dL) and emphasizes that the examiner should be experienced. ${ }^{7}$

The Canadian Urological Association (CUA) was the only entity to recommend the use of the total PSA/free PSA ratio as an instrument for SPCa because they consider that using the ratio improves specificity. ${ }^{10}$ The National Comprehensive Cancer Network (NCCN) panel group mentions several other markers (free PSA, 4Kscore, PCA3) that could be used: not for screening, but rather as ancillaries in the decision-making as to whether or not perform a biopsy in those with high PSA values. ${ }^{14}$

\section{At What age SHOULD SCREening Start AMONG MEN AT GENERAL RISK?}

This is the topic with the least dispersion across the guidelines, which recommend starting at $50^{7,8,10,11,15}$ or 55 years. ${ }^{6,9,17}$ The NCCN is the only entity that recommends screening at age 45 , irrespective of the presence of increased risk factors. They justify their stance by demonstrating that the studies on which others were based to define an age of onset did not investigate other age groups. They also show evidence that altered PSA results, even at very early ages, may predict $\mathrm{PCa}$ in the future. ${ }^{24,25}$

\section{At What AGE SHOULD SCREENING START AMONG MEN AT INCREASED RISK?}

Increased risk is reported for men of African descent and those with first-degree relatives (father or siblings) with PCa before 65 years. ${ }^{6,7,9-11,15}$ For those men, the recommendation is that screening should start at $40^{9,10}$ or 45 years. ${ }^{711,15}$ The ACS, which recommends starting at age 45 in patients at increased risk on the one hand, recommends starting at age 40 on the other hand in those ranked as at "higher risk," i.e. those having more than one first-degree relative with $\mathrm{PCa}{ }^{7}$

\section{WhAT IS THE INTERVAL BETWEEN SCREENINGS?}

This, in turn, is the topic of greatest dispersion among recommendations, varying from 1- to 8-year intervals.

The ACS uses PSA values for defining the time interval until the next scan, recommending that it occurs within one year if PSA is greater than or equal to $2.5 \mathrm{ng} / \mathrm{dL}$, or after two years if PSA is less than $2.5 \mathrm{ng} / \mathrm{dL} .^{7}$ The ACP also uses PSA values and recommends annual intervals if PSA > $2.5 \mathrm{ng} / \mathrm{dL}^{8}{ }^{8}$

The AUA recommends a biennial interval, highlighting it as the one preserving most of the advantages of the annual interval, while minimizing it harms. ${ }^{9}$ 
The UAE recommends the largest time interval between scans, which ranges from biennial, for those at highest risk, to up to 8 years, for those who are "not at risk," although they do not define who these patients are. ${ }^{11}$

Regardless of the time interval, and considering that medical knowledge is continuous and concepts can change, it is recommended that the physician should reassess the patient's life expectancy with each new screening. They should also discuss the potential benefits and harms with him again in light of the new data and knowledge. ${ }^{7}$

\section{At What age SHOULD SCREening BE DISCONTINUED?}

In general, the entities recommend that screenings should not be performed or should be discontinued altogether in men with a life expectancy of less than 10 or 15 years. The problem is that determining life expectancy is not a natural or habitual calculation for the physician, who tends to overestimate it and underestimate comorbidities. ${ }^{26,27}$ To assist the physician with her/his decision, entities bring examples of conditions that reduce life expectancy to levels below those cutoff points. The ACS mentions those patients having class IV (NYHA) heart failure, moderate to severe COPD, chronic renal failure, moderate to severe dementia, advanced cancer and other life-limiting comorbidities. ${ }^{7}$ For a more complete listing of comorbidities with an impact on survival rates, we refer to the Charlson Comorbidity Index. ${ }^{28}$

The entities that do define a point to discontinue screening, though, suggest doing so from the age of 70 years. ${ }^{6,8,9,12}$ The $\mathrm{AUA}^{9}$ considers that, in people aged 70 years or older, even when in good health, screening should be discouraged and even suspended if PSA levels are equal to or less than $3.0 \mathrm{ng} / \mathrm{dL}$. In contrast, the $\mathrm{NCCN},{ }^{14}$ once again in disagreement with the others, recommends that men older than 75 years should be screened provided they are in excellent health and have no comorbidities.

\section{WhAT SHOULD THE CUTOFF VALUE FOR "ALTERED" PSA BE?}

Classically, the cutoff value for considering an altered PSA has been $4 \mathrm{ng} / \mathrm{dL}$. Among large randomized trials, the $\mathrm{PLCO}^{4}$ uses $4 \mathrm{ng} / \mathrm{dL}$, and the $\mathrm{ERSPC}^{5}$ uses $3 \mathrm{ng} / \mathrm{dL}$ as a cutoff value to indicate biopsy. Most urologists prefer to use a $2.5 \mathrm{ng} / \mathrm{dL}$ cutoff value, while there are those who advocate different cutoff values according to age, although no cutoff value entirely satisfies the criteria for including all those who would benefit from being screened, which thus minimizes the number of overdiagnoses. ${ }^{7}$ In fact, the best course of action against an increased or unex- pected PSA result is repeating the test. The CUA recommends that no course of action should be taken based on a PSA result alone, since conditions other than cancer can cause it to fluctuate. ${ }^{10}$ The NCCN also recommends repeating all PSA tests $>3 \mathrm{ng} / \mathrm{dL} .{ }^{14}$ Simply repeating the test before any other course of action is decided upon could reduce overdiagnosis and its consequent harms.

The ACS recommends that men with PSA $\geq 4$ should be referred for further evaluation and biopsy. Those at increased risk (Afro-descendants, family history, older age or abnormal DRE findings) may be referred if PSA $>2.5 \mathrm{ng} / \mathrm{dL}$.

The EUA considers that men with PSA $>1 \mathrm{ng} / \mathrm{dL}$ at age 40 and those $>2 \mathrm{ng} / \mathrm{dL}$ at age 60 are at higher risk of presenting with PCa.

\section{Conclusion}

Considering that all the guidelines analyze the same problem (screening for PCa) and have the same goal (reducing mortality), it would be expected that there were no disparities across them. Yet, the problem was bigger in the past. By using an evidence-based perspective and multiprofessional analysis groups (epidemiologists, clinicians, urologists), the new guidelines are increasingly in tune. However, adherence to them remains very low, which increases the risk of overdiagnosis and harm to patients. ${ }^{19}$

When analyzing the most relevant points for the clinician's practice, we identified six recommendations that sum up the majority thereof and, for the sake of simplicity, facilitate their routine use:

1. Recommendation: Screening should be discussed with the patient, after he has been made aware of the limitations and harms caused by the procedure. This discussion, and the patient approval, must be considered a sine qua non condition to screening. The clinician should use the educational material produced by the entities, or any other reliable sources, matching the patient's level of understanding.

2. Tests to be used: PSA dosing, either coupled with the digital rectal examination or not.

3. Age of onset for screening in individuals at general risk: 50-55 years, at the discretion of the physician and the patient.

4. Age of onset for screening in individuals at increased risk: 40 or 45 years, at the discretion of the physician and the patient.

5. Interval between screenings: Annual or biennial, at the discretion of the physician and the patient.

6. Discontinuation of screening: 70 years or when life expectancy is less than 10 years. 
With respect to PSA cutoff values, given the great divergence found in the literature and the fact that the subject has been approached by few entities, there is no common ground. It is prudent to repeat the test to confirm any changes and refer the patient to a specialist with experience in diagnosing and treating prostate cancers.

We believe that this minimal set of recommendations can aid in disseminating and promoting adherence to evidence-based practices for such an important male health problem like prostate cancer.

\section{Resumo}

Guias de conduta vigentes para o rastreamento do câncer de próstata: uma revisão sistemática e proposta de núcleo mínimo

Objetivo: Considerando a importância do rastreamento de câncer de próstata, a possibilidade de dano decorrente do rastreamento indiscriminado, a dificuldade de divulgação e adesão às diretrizes sobre o assunto, objetivamos identificar as principais diretrizes vigentes, procurar pontos de abordagem comuns e estabelecer um núcleo mínimo de condutas.

Método: Revisão sistemática da literatura sobre guias de prática de rastreamento para câncer de próstata nas bases Pubmed, Lilacs e Google Scholar, além de busca ativa nos sítios de diversas entidades de saúde nacionais.

Resultados: Foram selecionadas 12 diretrizes, cuja análise resultou na identificação de seis pontos comuns de conduta, com o seguinte núcleo mínimo de recomendações: (1) a indicação ou não de rastreamento: deve ser individualizada e precedida de uma decisão informada; (2) os exames utilizados: PSA com ou sem exame digital retal; (3) a idade de início geral: 50-55 anos; (4) a idade de início em homens com risco aumentado: 40 anos; (5) o intervalo entre os rastreamentos: anual ou bienal; e (6) a idade de suspensão do rastreamento: 70 anos ou expectativa de vida menor que 10 anos.

Conclusão: Embora existam divergências entre elas, foi possível estabelecer um núcleo mínimo de condutas que podem ser úteis na prática diária do médico.

Palavras-chave: Programas de Rastreamento. Rastreamento. Neoplasias da Próstata. Câncer de Próstata. Guias de Prática Clínica.

\section{References}

1. Global Burden of Disease Cancer Collaboration, Fitzmaurice C, Dicker D, Pain A, Hamavid H, Moradi-Lakeh M, MacIntyre M, et al. The Global Burden of Cancer 2013. JAMA Oncol. 2015;1(4):505-27.

2. Instituto Nacional do Câncer. Estimativa da incidência de câncer no Brasil. [cited 2017 Mar 26]. Available from: http://www.inca.gov.br/estimativa/2014/ sintese-de-resultados-comentarios.asp.

3. Horner MJ, Ries LAG, Krapcho M, et al. SEER Cancer Statistics Review, 1975-2006. Bethesda. [cited 2017 Mar 26]. Available from: https://seer.cancer. gov/archive/csr/1975_2006/results_merged/sect_23_prostate.pdf.

4. Andriole GL, Crawford ED, Grubb RL 3rd, Buys SS, Chia D, Church TR, et al; PLCO Project Team. Mortality results from a randomized prostate-cancer screening trial. N Engl J Med. 2009;360(13):1310-9.

5. Schröder FH, Hugosson J, Roobol MJ, Tammela TL, Ciatto S, Nelen V, et al; ERSPC Investigators. Screening and prostate-cancer mortality in a randomized European study. N Engl J Med. 2009;360(13):1320-8.

6. Canadian Task Force on Preventive Health Care, Bell N, Connor Gorber S, Shane A, Joffres M, Singh H, Dickinson J, et al. Recommendations on screening for prostate cancer with the prostate-specific antigen test. CMAJ. 2014;186(16):1225-34.

7. Wolf AMD, Wender RC, Etzioni RB, Thompson IM, D'Amico AV, Volk RJ, et al; American Cancer Society Prostate Cancer Advisory Committee. American Cancer Society guideline for the early detection of prostate cancer: update 2010. CA Cancer J Clin. 2010;60(2):70-98.

8. Qaseem A, Barry MJ, Denberg TD, Owens DK, Shekelle P; Clinical Guidelines Committee of the American College of Physicians. Screening for prostate cancer: a guidance statement from the Clinical Guidelines Committee of the American College of Physicians. Ann Intern Med. 2013;158(10):761-9.

9. Carter HB, Albertsen PC, Barry MJ, Etzioni R, Freedland SJ, Greene KL, et al. Early detection of prostate cancer: AUA Guideline. J Urol. 2013;190(2):419-26.

10. Izawa JI, Klotz L, Siemens DR, Kassouf W, So A, Jordan J, et al. Prostate cancer screening: Canadian guidelines 2011. Can Urol Assoc J. 2011;5(4):235-40.

11. Heidenreich A, Bastian PJ, Bellmunt J, Bolla M, Joniau S, van der Kwast T, et al; European Association of Urology. EAU guidelines on prostate cancer. part 1: screening, diagnosis, and local treatment with curative intent-update 2013. Eur Urol. 2014;65(1):124-37.

12. Parker C, Gillessen S, Heidenreich A, Horwich A; ESMO Guidelines Committee. Cancer of the prostate: ESMO Clinical Practice Guidelines for diagnosis, treatment and follow-up. Ann Oncol. 2015;26(Suppl 5):v69-v77.

13. Instituto Nacional do Câncer. Rastreamento do câncer de próstata. 2013. [cited 2017 Mar 26]. Available from: http://www1.inca.gov.br/inca/Arquivos/ rastreamento_prostata_resumido.2013.pdf

14. Carroll PR, Parsons JK, Andriole G, Bahnson RR, Barocas DA, Castle EP, et al. NCCN Clinical practice guidelines prostate cancer early detection, Version 2.2015. J Natl Compr Canc Netw. 2015;13(12):1534-61.

15. Dall'Oglio MF, Crippa A, Faria EF, et al. Rastreamento do câncer de próstata. Rio de Janeiro: Sociedade Brasileira de Urologia; 2011.

16. Moyer VA; U.S. Preventive Services Task Force. Screening for prostate cancer: U.S. Preventive Services Task Force recommendation statement. Ann Intern Med. 2012;157(2):120-34.

17. Bibbins-Domingo K, Grossman DC, Curry SJ. The US Preventive Services Task Force 2017 Draft recommendation statement on screening for prostate cancer: an invitation to review and comment. JAMA. 2017(19):1949-50.

18. Hoag NA, So AI. The confusion surrounding prostate cancer screening faced by family physicians. Can Urol Assoc J. 2012;6(3):194-5.

19. Roobol M. Perspective: Enforce the clinical guidelines. Nature. 2015; 528(7582):S123.

20. Liberati A, Altman DG, Tetzlaff J, Mulrow C, Gøtzsche PC, Ioannidis JP, et al. The PRISMA statement for reporting systematic reviews and metaanalyses of studies that evaluate health care interventions: explanation and elaboration. PLoS Med. 2009;6(7):e1000100.

21. Dunn AS, Shridharani K V, Lou W, Bernstein J, Horowitz CR. Physicianpatient discussions of controversial cancer screening tests. Am J Prev Med. 2001;20(2):130-4. 
22. Hoffman RM, Elmore JG, Fairfield KM, Gerstein BS, Levin CA, Pignone MP. Lack of shared decision making in cancer screening discussions: results from a national survey. Am J Prev Med. 2014;47(3):251-9.

23. Alberts AR, Schoots IG, Roobol MJ. Prostate-specific antigen-based prostate cancer screening: Past and future. Int J Urol. 2015;22(6):524-32.

24. Lilja H, Cronin AM, Dahlin A, Manjer J, Nilsson PM, Eastham JA, et al. Prediction of significant prostate cancer diagnosed 20 to 30 years later with a single measure of prostate-specific antigen at or before age 50 .

25. Vickers AJ, Ulmert D, Sjoberg DD, Bennette CJ, Björk T, Gerdtsson A, et al. Strategy for detection of prostate cancer based on relation between prostate specific antigen at age 40-55 and long term risk of metastasis: case-control study. BMJ. 2013;346:f2023.

26. Daskivich TJ, Chamie K, Kwan L, Labo J, Dash A, Greenfield S, et al. Comorbidity and competing risks for mortality in men with prostate cancer. Cancer. 2011;117(20):4642-50.

27. Daskivich TJ, Chamie K, Kwan L, Labo J, Palvolgyi R, Dash A, et al Overtreatment of men with low-risk prostate cancer and significant comorbidity. Cancer. 2011;117(10):2058-66.

28. Charlson ME. Charlson Comorbidity Index. [cited 2017 Mar 26]. Available from: http://www.bgs.org.uk/pdfs/assessment/cci.pdf. 